\title{
MAPPING THE CHARACTERISTICS OF TROPICAL FOREST PEAT AND CULTIVATED PEAT UNDER OIL PALM PLANTATION IN SARAWAK, BORNEO
}

\section{SIONG FONG SIM*; CECELYEA JUMIN* and KHO LIP KHOON**}

\begin{abstract}
This study attempts to establish and map the characteristics of peat soil under oil palm plantation and forest ecosystem. Peat soil from oil palm plantation and forest was collected for analysis at the depths of $0-15 \mathrm{~cm}, 100 \mathrm{~cm}, 200 \mathrm{~cm}$ and $300 \mathrm{~cm}$. The plantation peat was found richer with exchangeable calcium and potassium likely due to the fertilisation and liming practices at the estate. The carbon dioxide $\left(\mathrm{CO}_{2}\right)$ flux was detected higher at the plantation with elevated emission recorded near the drainage canal. As the depth increased, moisture was evidenced to surge with declining bulk density, indicative of less decomposed underlying peat. The $E_{4} / E_{6}$ values, however, did not reveal any statistical difference in peat soil from different land use and depths. The carbon-to-nitrogen $(C / N)$ ratio was found lower in the cultivated peat suggesting reduced nitrogen stores. This was likely associated with the plantation management practices, resulting in enhanced mineralisation of nitrogen. The $C / N$ ratio was evidenced to increase with increasing depths in both plantation and forest, indicative of lower humification degree for the horizon peat. It was concluded that the soil characteristics differed between land use and depths with spatial variations within each land use.
\end{abstract}

Keywords: humification degree, $\mathrm{E}_{4} / \mathrm{E}_{6}$, carbon-to-nitrogen ratio, $\mathrm{CO}_{2}$ emission, characteristics maps.

Date received: 17 March 2019; Sent for revision: 5 April 2019; Received in final form: 27 July 2019; Accepted: 1 August 2019.

\section{INTRODUCTION}

A total of 1.6 million hectares of peatland is found in Sarawak, accounting for $66 \%$ of the total peatland in Malaysia. It is largely used for agriculture purposes

\footnotetext{
* Faculty of Resource Science \& Technology,

Universiti Malaysia Sarawak,

94300 Kota Samarahan,

Sarawak, Malaysia.

E-mail: sfsim@unimas.my

** Malaysian Palm Oil Board,

6 Persiaran Institusi, Bandar Baru Bangi,

43000 Kajang, Selangor, Malaysia.
}

including oil palm and sago palm plantations. One of the challenges of planting on peat is that their yield is generally lower. According to Melling (2000), the degree of humification is an imperative factor governing the productivity of agriculture development on peat. It has profound effects on the bulk density, moisture holding capacity and nutrient availability of the soil. Veloo et al. (2015) similarly inferred that peat maturity has the most significant effect on the yield; the presence of undecomposed wood in the tropical peat profile was reported to relate to poor rooting and inadequate nutrient uptake in oil palm leading to pre-mature dehydration of 
fronds. In the experience of sago plantation on the other hand, the palms are unable to produce trunk upon maturity (Sim et al., 2017).

Peat is formed from the partially decomposed organic materials. During the decomposition process, a stabilised organic substance (referred to as humic substances) consisting of hydrophobic and hydrophilic functional groups is produced (Maryganova et al., 2010). These humified materials serve to agglutinate soil (Clapp et al., 1999), improving aeration and water retention capacity which ultimately lead to increased crop production (Piccolo, 2002). As reported by Venegas-Gonzàlez et al. (2013), blackberry planted in better humified compost demonstrates improved nutrient uptake.

Peat maturity is a crucial factor determining the productivity of the organic soil. However, limited information is available for agricultural development on peatland. Typically, the land suitability is mainly assessed based on the soil depth and its drainability (Veloo et al., 2014; Paramanathan and Omar, 2015). In this study, we attempt to establish the characteristics of forest and cultivated peat where the characteristics were latter mapped to depict the spatial variability in humification degree. The variation in chemical and physical properties can be used to describe the degree of decomposition; for example, undecomposed peat characteristically demonstrates low bulk density with high fibre content. These maps are simple representations of bulk soil data that can be used for planning, utilisation and management of peatland. Essentially, peat is highly vulnerable to decomposition upon drainage and compression. With understanding on the spatial variability of humification degree, it is possible to zone the peat according to their suitability and readiness for agriculture purposes, i.e. mature peat can be utilised while young peat is conserved.

\section{MATERIALS AND METHODS}

\section{Study Sites}

Peat soil samples were collected from a 1 ha plot in Sebungan Oil Palm Estate (N 03 09' 58.32" E $113^{\circ}$ $\left.21^{\prime} 15.43^{\prime \prime}\right)$ and Sebaju 4 Forest (N 03 ${ }^{\circ} 09^{\prime} 58.32^{\prime \prime} \mathrm{E}$ $\left.113^{\circ} 24^{\prime} 21.32^{\prime \prime}\right)$, respectively in Sarawak, Malaysia as shown in Figure 1.

The 1 ha plot consisted of 25 subplots, each with dimensions of $20 \mathrm{~m} \times 20 \mathrm{~m}$, labelled and represented schematically in Figure 2. The peat soil of Sebungan Estate has a depth of $1 \mathrm{~m}$ to more than $3 \mathrm{~m}$ whilst at the secondary forest, the depth is uncharacterised. The water table was maintained at $30-40 \mathrm{~cm}$ below the surface in Sebungan Estate whilst the water table in Sebaju Forest was unregulated.

\section{Sampling}

Three soil samples were randomly collected at the area under the vegetation canopies within a subplot. The samples were taken from the surface at $0-15 \mathrm{~cm}$ and at the depth of $100 \mathrm{~cm}, 200 \mathrm{~cm}$ and $300 \mathrm{~cm}$ using an Eijkelkamp gouge auger with extension rod (core diameter $52 \mathrm{~mm}$, length $0.5 \mathrm{~m}$ ). The samples were removed from the auger, placed in ziplock bags and labelled according to subplots.

\section{Sample Preparation and Analyses}

The soil samples were air-dried, ground into fine particles and sieved through $2 \mathrm{~mm}$ sieve. The samples were subjected to analyses in triplicates that included moisture content, bulk density, $\mathrm{pH}$, electrical conductivity, ash content, exchangeable bases, cation exchange capacity (CEC) and humification degree. Note that for the underlying peat at 100, 200 and $300 \mathrm{~cm}$, the samples were only

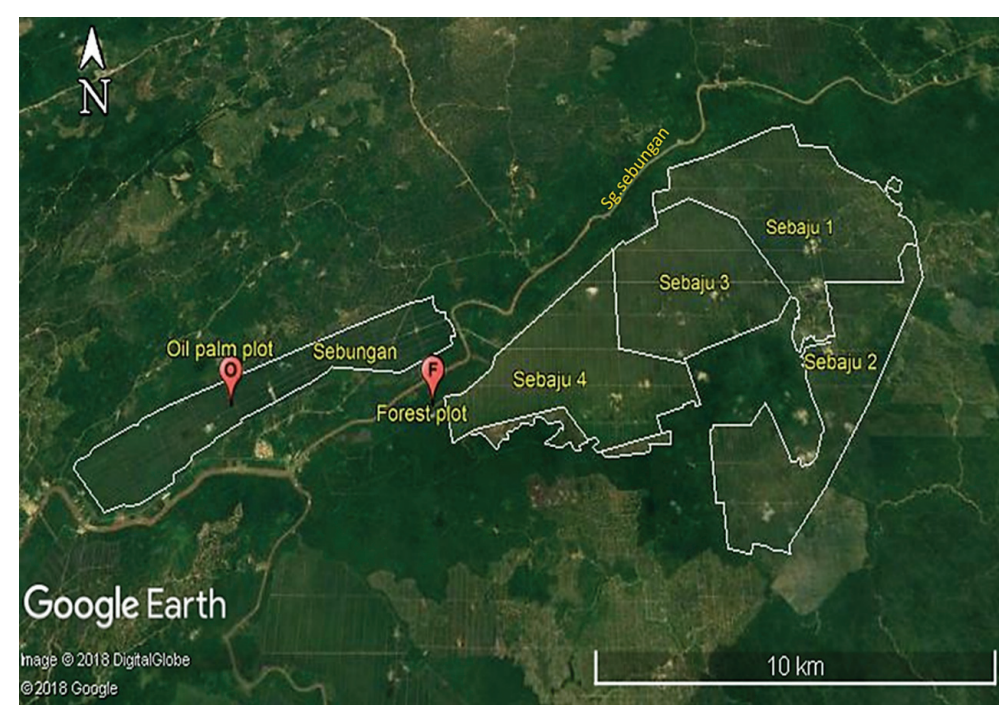

Figure 1. The sampling plot in Sebungan Estate and Sebaju Forest. 


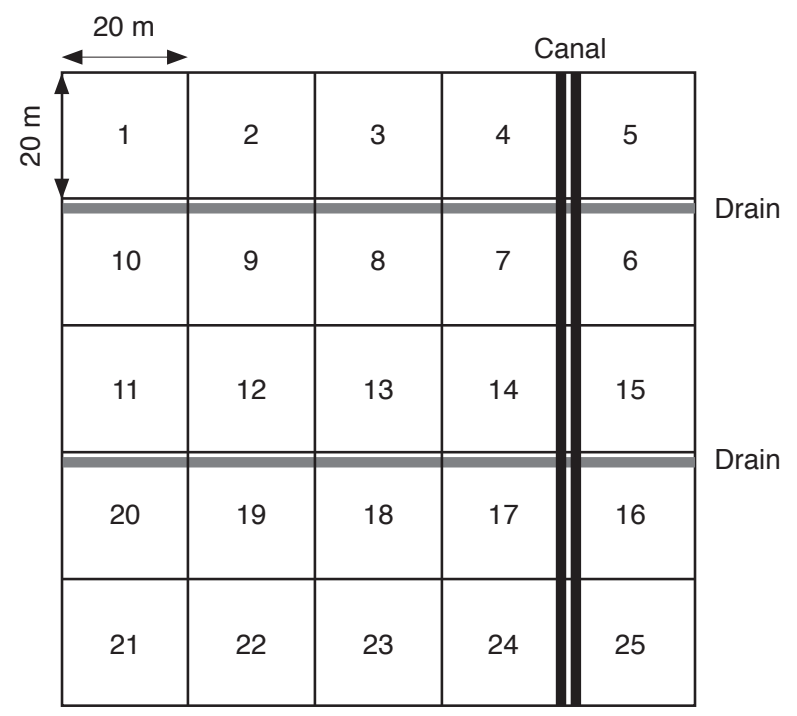

(a) Oil palm plantation

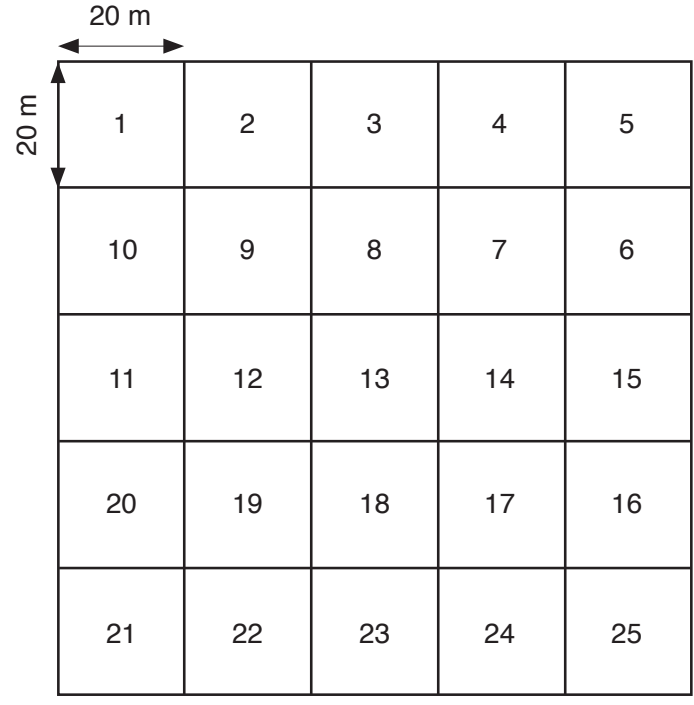

(b) Forest

Figure 2. Schematic representation of subplots in (a) oil palm plantation and (b) forest.

analysed for moisture, $\mathrm{pH}$, electrical conductivity and humification degree. Carbon dioxide $\left(\mathrm{CO}_{2}\right)$ emission from 25 subplots in oil palm plantation and forest was also measured using EGM-4 InfraRed Gas Analyser (IRGA) system according to Marthews et al. (2014).

The $\mathrm{pH}$ and electrical conductivity were measured using a $\mathrm{pH} /$ conductivity meter $(\mathrm{EXTECH}$ ExStik II) in a soil to water suspension of 1:5 (McLean, 1982). The moisture was measured based on loss on drying whilst the ash content was determined according to the loss-on-ignition method (ASTM, 1987). For ash content, the soil sample was dried in an oven at $100^{\circ} \mathrm{C}$ overnight. One gram of the dried soil was then weighed into a crucible and combusted in a furnace at $550^{\circ} \mathrm{C}$ for $6 \mathrm{hr}$. Bulk density was the ratio of oven dried mass of the soil to its volume where the soil was dried until constant weight was attained (Blake, 1965).

For exchangeable bases, $2 \mathrm{~g}$ of soil $(\leq 2 \mathrm{~mm})$ were weighed in a $100 \mathrm{ml}$ Erlenmeyer flask and added with $40 \mathrm{ml}$ of $1 \mathrm{M}$ ammonium acetate $\left(\mathrm{NH}_{4} \mathrm{OAc}\right)$, prepared from glacial acetic acid and concentrated ammonium hydoxide. The sample was left overnight and filtered through a $0.45 \mu \mathrm{m}$ membrane filter. This process was repeated four times with $25 \mathrm{ml}$ of $1 \mathrm{M} \mathrm{NH}_{4} \mathrm{OAc}$. The leachate was transferred into a $250 \mathrm{ml}$ volumetric flask and made up to mark with deionised water. The filtrate was analysed for exchangeable bases $(\mathrm{Ca}, \mathrm{Mg}, \mathrm{Na}$ and K) using the Inductively Coupled Plasma Optical Emission Spectrophotometer (Perkin Elmer, Optima 800) (Li et al., 2016).

For determination of CEC, excess $\mathrm{NH}_{4} \mathrm{OAc}$ in soil was leached with $150 \mathrm{ml}$ ethanol to wash away all the electrolytes and the leachate was discarded. The soil sample was then leached with $250 \mathrm{ml}$ of
$10 \%$ acidified $\mathrm{NaCl}$. The leachate was transferred to $800 \mathrm{ml} \mathrm{Kjeldahl} \mathrm{flask} \mathrm{and} \mathrm{added} \mathrm{with} 25 \mathrm{ml}$ of 1 $\mathrm{M} \mathrm{NaOH}$. A $60 \mathrm{ml}$ volume of the solution was then distilled into $50 \mathrm{ml}$ of $2 \%$ boric acid. The solution was titrated with $0.1 \mathrm{M} \mathrm{HCl}$ to determine the adsorbed $\mathrm{NH}_{4}{ }^{+}$in the presence of bromocresol green - methyl red as the indicator. At the end point, the colour changed from bluish green to pink. Blank samples were analysed on each run. The CEC was calculated in the unit of $\mathrm{cmol}_{\mathrm{c}} \mathrm{kg}^{-1}$. The exchangeable bases and CEC were according to the US EPA Method 9080 (1986) and calculated according to the following equations.

CEC $\left(\mathrm{NH}_{4}^{+}\right)$equation for titration method in $\mathrm{cmol}_{c} \mathrm{~kg}^{-1}$ soil is:

$$
\mathrm{CEC}=\frac{(\text { Sample }- \text { blank titre }) \times \text { molarity of } \mathrm{HCl} \times 100}{\text { Weight of soil taken }(\mathrm{g})}
$$

Exchangeable cations $\left(\mathrm{cmol}_{c^{\prime}} \cdot \mathrm{kg}^{-1}\right)=\frac{\mathrm{s} \times \mathrm{v}}{\mathrm{m} \times \mathrm{j} \times 10^{3}} \times 100$

where:

$\mathrm{s}=$ Concentration of cation $\left(\mathrm{mg}\right.$ litre $\left.^{-1}\right)$

$\mathrm{V}=$ Volume of leachate samples $(\mathrm{ml})$

$\mathrm{m}=$ Weight of soil sample $(\mathrm{g})$

$\mathrm{j}=$ Molar mass of the element $\left(\mathrm{g} \mathrm{mol}^{-1}\right)$

The humification index was determined using the UV-Vis spectrophotometer. A $0.5 \mathrm{~g}$ of peat soil was added with $60 \mathrm{ml}$ of $0.5 \% \mathrm{NaOH}$ and centrifuged at $3600 \mathrm{rpm}$ for $15 \mathrm{~min}$. The supernatant was transferred into a $50 \mathrm{ml}$ beaker and acidified with $0.6 \mathrm{M}$ of concentrated $\mathrm{HCl}$ until $\mathrm{pH}$ 1. The solution was left to stand for $1 \mathrm{hr}$ for the humic acid fraction to precipitate. The solution was then centrifuged at $4000 \mathrm{rpm}$ for $15 \mathrm{~min}$. The supernatant was discarded; the precipitate was washed with distilled water and 
centrifuged for $5 \mathrm{~min}$. The humic acid fraction was dissolved in $5 \mathrm{ml}$ of $0.1 \mathrm{M} \mathrm{NaOH}$ and the solution was brought to mark in a $100 \mathrm{ml}$ volumetric flask (Khan et al., 2006). The absorbance at $\mathrm{E}_{465}$ and $\mathrm{E}_{665}$ $\mathrm{nm}$ was recorded using a UV-Vis spectrophotometer (Shimadzu, UV-1800). The humification index was measured based on absorbance at 465 and $665 \mathrm{~nm}$, often referred to as $E_{4} / E_{6}$. The carbon and nitrogen content of composite soils from 25 subplots at each profile were measured using a carbon and nitrogen analyser (LECO) in triplicates. The samples were heated at $60^{\circ} \mathrm{C}$ for $24 \mathrm{hr}$ prior to analysis.

\section{$\mathrm{CO}_{2}$ Emission}

Two PVC collars of approximately $10 \mathrm{~cm}$ in length were installed at each subplot in Sebungan Estate and Sebaju Forest yielding a total of 100 collars. The PVC collar was gently hammered into the soil at each subplot. Before the collar insertion, the vegetation and litter were removed to minimise the influence of litter decomposition and root respiration on the measurement (Hergoualc'h and Verchot, 2013). The collar was labelled and left for a week. The $\mathrm{CO}_{2}$ emission was measured after one week. At each measurement, the height of the collar as well as the soil moisture, soil temperature and air temperature were recorded. The carbon dioxide emission was calculated according to the following equations.

Raw carbon dioxide measurement:

$\mathrm{R}_{\mathrm{uc}}=\frac{\mathrm{C}_{\mathrm{f}}-\mathrm{C}_{\mathrm{i}}}{\mathrm{t}_{\mathrm{f}}-\mathrm{t}_{\mathrm{i}}} \times \frac{\mathrm{p}}{\left(\mathrm{T}_{\mathrm{a}}+273.15\right)} \times \frac{\mathrm{V}_{\mathrm{d}}}{\mathrm{A}} \times \frac{44.01 \times 0.36}{\mathrm{R}_{\mathrm{u}}} \mathrm{g} \mathrm{CO}_{2} \mathrm{~m}^{-2} \mathrm{hr}^{-1}$

Corrected carbon dioxide measurement:

$\mathrm{R}_{\mathrm{c}}=\mathrm{R}_{\mathrm{uc}} \times \frac{\mathrm{V}_{\mathrm{d}}+\mathrm{V}_{\text {added }}}{\mathrm{V}_{\mathrm{d}}} \mathrm{gCO}_{2} \mathrm{~m}^{-2} \mathrm{hr}^{-1}$

Volume of collar:

$\mathrm{V}_{\text {added }}\left(\mathrm{Cm}^{3}\right)=3.1416 \times\left(\frac{\mathrm{d}_{\text {Collar }}}{2}\right)^{2} \times h r$

where:

$\mathrm{R}_{\mathrm{uc}}$ is uncorrected $\mathrm{CO}_{2}$ efflux $\left(\mathrm{g} \mathrm{CO}_{2} \mathrm{~m}^{-2} \mathrm{hr}^{-1}\right)$

$\mathrm{R}_{\mathrm{c}}$ is corrected $\mathrm{CO}_{2}$ efflux $\left(\mathrm{g} \mathrm{CO}_{2} \mathrm{~m}^{-2} \mathrm{hr}^{-1}\right)$

$t_{\mathrm{f}}$ and $t_{\mathrm{i}}$ are the final and initial times (s)

$\mathrm{C}_{\mathrm{f}}$ and $\mathrm{C}_{\mathrm{i}}$ are the final and initial $\mathrm{CO}_{2}$ concentrations (ppmv)

$\mathrm{P}$ is ambient pressure at time $\left(\mathrm{t}_{\mathrm{i}}\right)$

$\mathrm{T}_{\mathrm{a}}$ is air temperature at $\mathrm{t}_{\mathrm{f}}\left({ }^{\circ} \mathrm{C}\right)$

$V_{d}$ is the SRC-1 chamber volume which is $0.0012287 \mathrm{~m}^{3}$.

$A$ is the area exposed soil which the SRC+ collar have been placed.

$R_{u}$ is the universal gas constant which is $8.31432 \mathrm{~J} \mathrm{~mol}^{-1} \mathrm{~K}^{-1}$

\section{Data Analysis}

The average measurements attained for each subplot were arranged into a matrix with rows representing subplots and columns denoting variables. The dimensions of the matrix were $25 \times 12$ for surface soil and $25 \times 5$ for the lower peat layers. The measurements of each variable $(25 \times 1)$ were organised into a matrix of $5 \times 5$ according to the subplot in Figure 2 and illustrated on colour maps. Two sample t-test with equal mean was used to compare the mean between two sample groups at $95 \%$ significant difference. Analysis of variance (ANOVA) was employed to compare the mean of more than two sample groups with Tukey's test applied for multiple comparisons at 95\% significant difference.

\section{RESULTS AND DISCUSSION}

Figure 3 illustrates the characteristics maps of surface peat from the oil palm plantation and forest. Statistically, there was a significant different in conductivity, exchangeable cations $(\mathrm{Mg}, \mathrm{Na}, \mathrm{K}$ and $\mathrm{Ca}$ ) and $\mathrm{CO}_{2}$ emission $(\mathrm{p}<0.05)$.

The conductivity of forest peat was higher than that from the plantation, with richer exchangeable $\mathrm{Na}$ and $\mathrm{Mg}$ in the former whilst $\mathrm{Ca}$ and $\mathrm{K}$ predominated the latter. This concurs with the findings of Sulistiyanto et al. (2007) who reported higher $\mathrm{Mg}$ and $\mathrm{Na}$ in peat water at the forest sites whilst $\mathrm{K}$ was more prominent in the deforested area. Peat soil is naturally susceptible to leaching of $\mathrm{K}$ due to low level of clay content and absence of mineral matter (Ahmed et al., 2005). In agricultural practices, fertilisers are used to improve the retention of $\mathrm{K}$ in peat (Ahmed et al., 2015). It is hence believed that the more pronounced $\mathrm{K}$ and $\mathrm{Ca}$ in the plantation is a result of liming and fertiliser applications at the estate. The lower $\mathrm{Mg}$ and $\mathrm{Na}$ in the reclaimed ecosystem is possibly due to leaching; Suharjo and Nurhayati (2005) revealed that the nutrients are susceptible to loss, especially after burning. For $\mathrm{CO}_{2}$ emission, oil palm plantation was found to release significantly higher $\mathrm{CO}_{2}$ than that from the forest with cumulative flux of 1.61 and $1.04 \mathrm{~kg} \mathrm{CO}_{2} \mathrm{~m}^{-2} \mathrm{yr}^{-1}$, respectively. The emission recorded at the plantation is comparable with the measurement reported by Melling et al. (2007) at $1.54 \mathrm{~kg} \mathrm{CO}_{2} \mathrm{~m}^{-2} \mathrm{yr}^{-1}$. For the emission from forest, however, the measurement recorded is lower than the findings of Melling et al. (2007) at $2.13 \mathrm{~kg} \mathrm{CO} \mathrm{m}^{-2} \mathrm{yr}^{-1}$ The controlling factor of $\mathrm{CO}_{2}$ emission is the drainage (Ishikura et al., 2018). In the process of reclamation, drainage may foster mineralisation of organic matter leading to increase in $\mathrm{CO}_{2}$ flux (Gronlund et al., 2008) hence it is important to manage the water table for sustainable development of peat. The characteristic maps further suggest that $\mathrm{CO}_{2}$ emission from the estate is generally more heterogeneous than that occurring in the forest. A higher $\mathrm{CO}_{2}$ flux was identified at subplots near the access road (subplots 11 and 20) and drainage canal (subplots 7, 14 

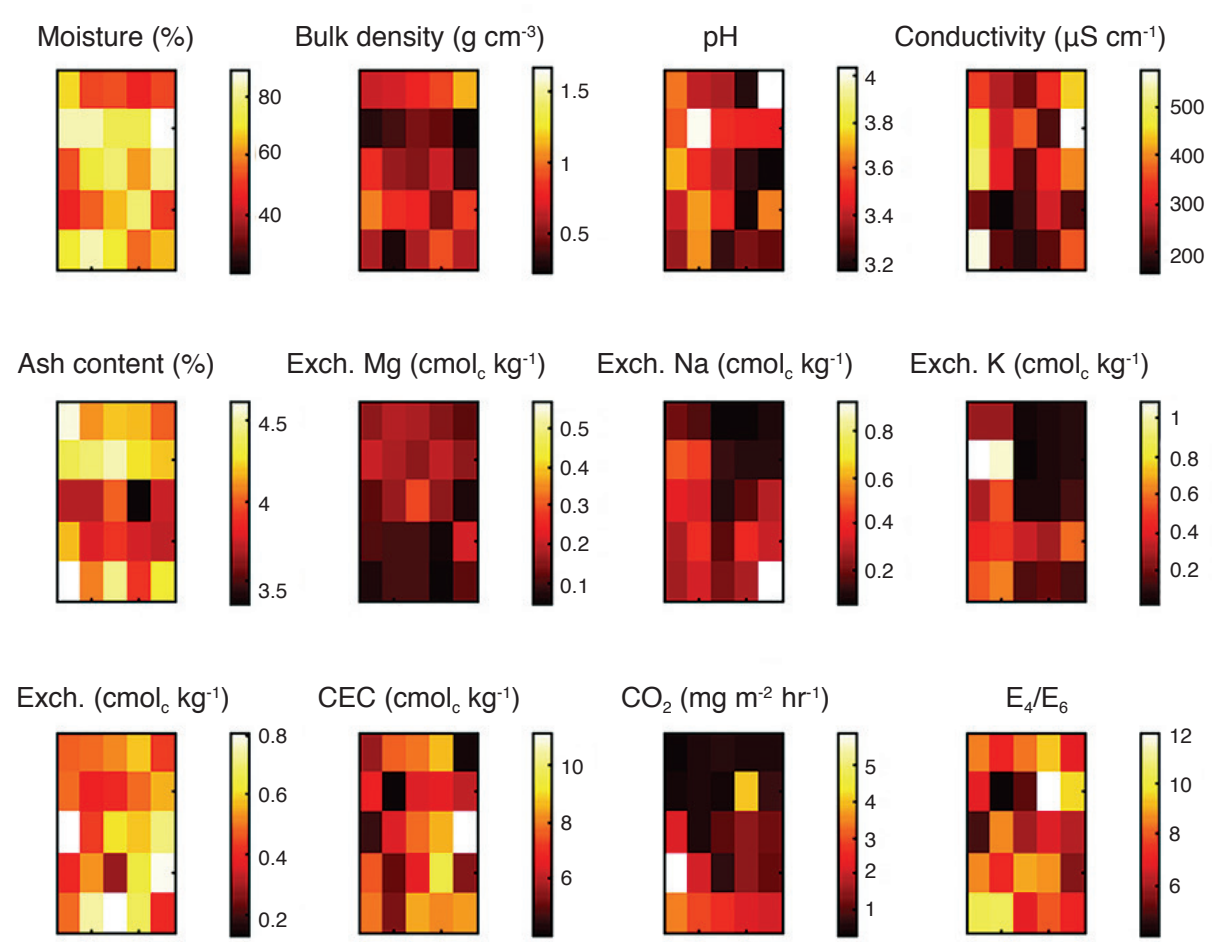

(a) Oil palm plantation

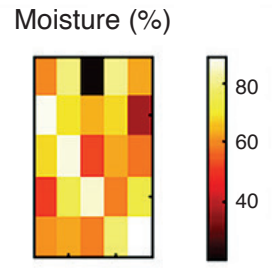

Bulk density $\left(\mathrm{g} \mathrm{cm}^{-3}\right)$
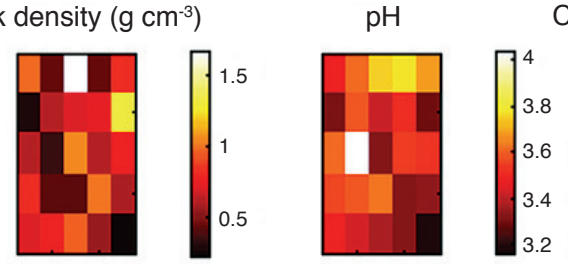

Conductivity $\left(\mu \mathrm{S} \mathrm{cm}{ }^{-1}\right)$

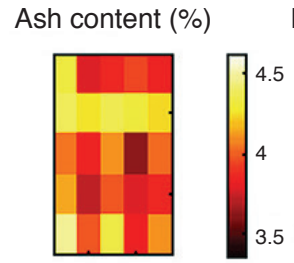

Exch. $\mathrm{Mg}\left(\mathrm{cmol}_{\mathrm{c}} \mathrm{kg}^{-1}\right)$

\section{Exch.}
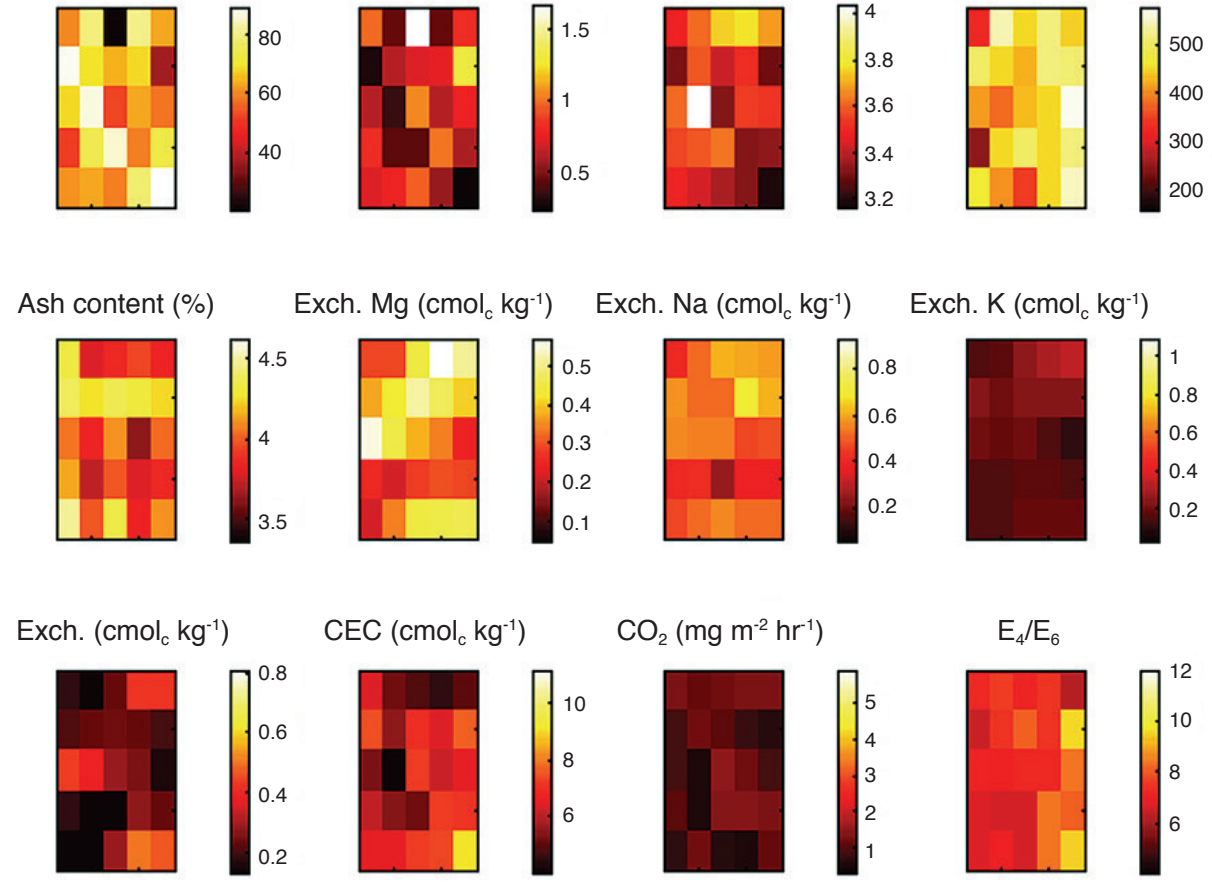

$\mathrm{CO}_{2}\left(\mathrm{mg} \mathrm{m}^{-2} \mathrm{hr}^{-1}\right)$

$\mathrm{E}_{4} / \mathrm{E}_{6}$
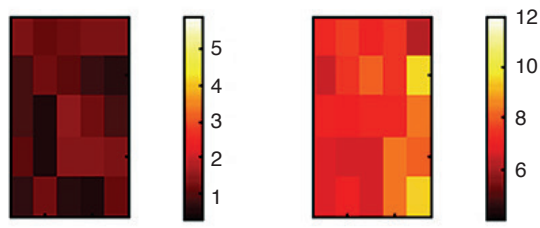

(b) Forest

Figure 3. Characteristics maps of surface peat from oil palm plantation and forest.

and 17) in the plantation. This suggests that the conversion and drainage of peatland has an effect on the $\mathrm{CO}_{2}$ emission. Spatial variability in methane flux was similarly reported in drained peatland as a result of vegetation heterogeneity and ditches (Minkinnen and Laine, 2006). Premke et al. (2016) further corroborated the variation in carbon fluxes from five different landscapes, associating with the landscape heterogeneity and diversity. The profile maps of moisture, $\mathrm{pH}$, bulk density, conductivity and humification degree are shown in Figure 4 with the average characteristics summarised in Table 1. 
The profile maps confirm that the soil was completely submerged at $100 \mathrm{~cm}, 200 \mathrm{~cm}$ and $300 \mathrm{~cm}$ for both plantation and forest peat. The soil $\mathrm{pH}$ and conductivity were found to decline with increasing depths $(\mathrm{p}<0.05)$. The bulk density of the surface peat was also notably higher than the underlying peat for both sites with statistical difference $(\mathrm{p}<0.05)$; this opposes the findings reported on the temperate peat where the bulk density was found to increase with depths (Ott and Chimner, 2016). Bulk density is an indicator of decomposition; the bulk density may range from $0.05 \mathrm{~g} \mathrm{~cm}^{-3}$ for poorly decomposed

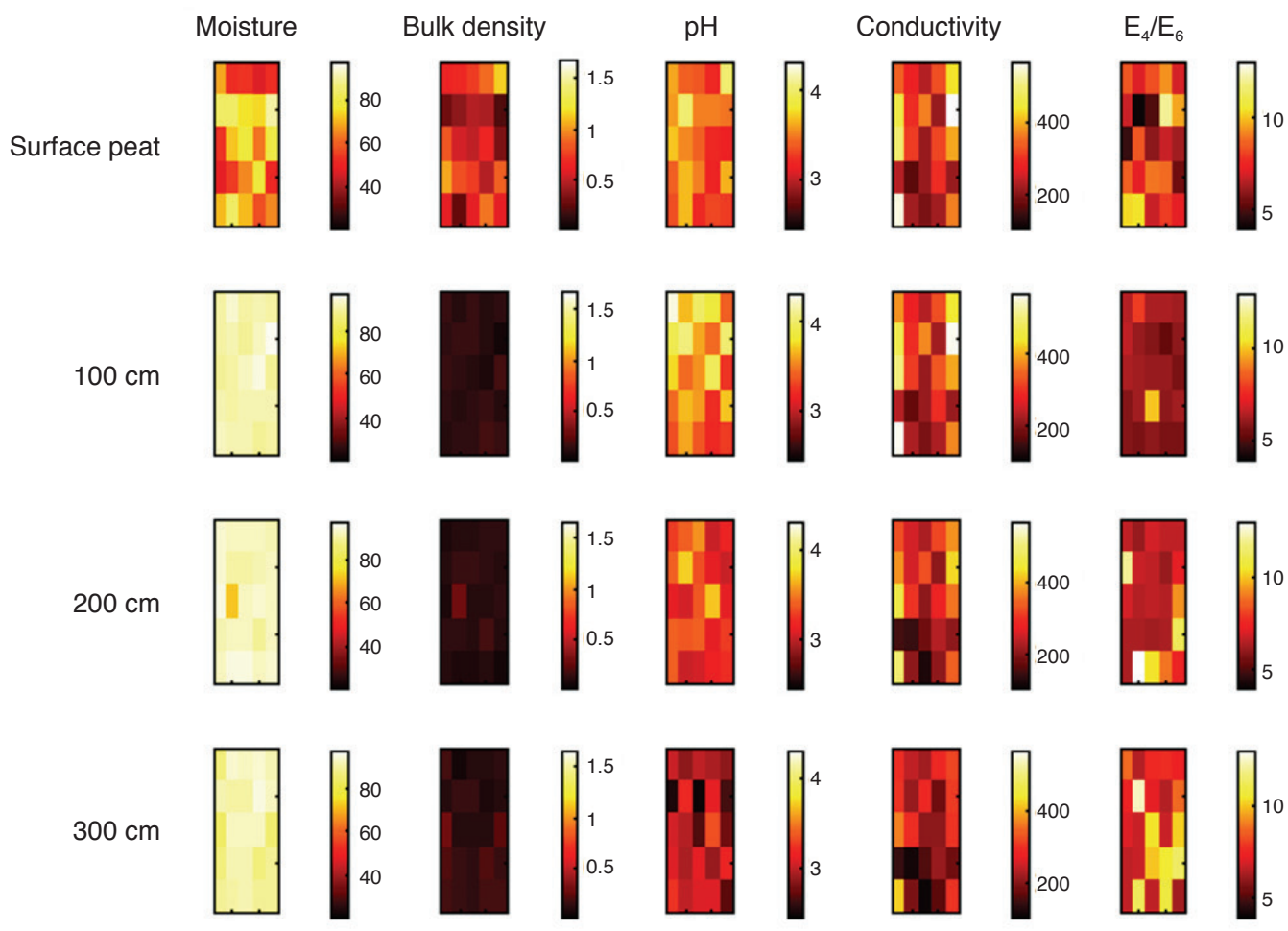

(a) Oil palm plantation

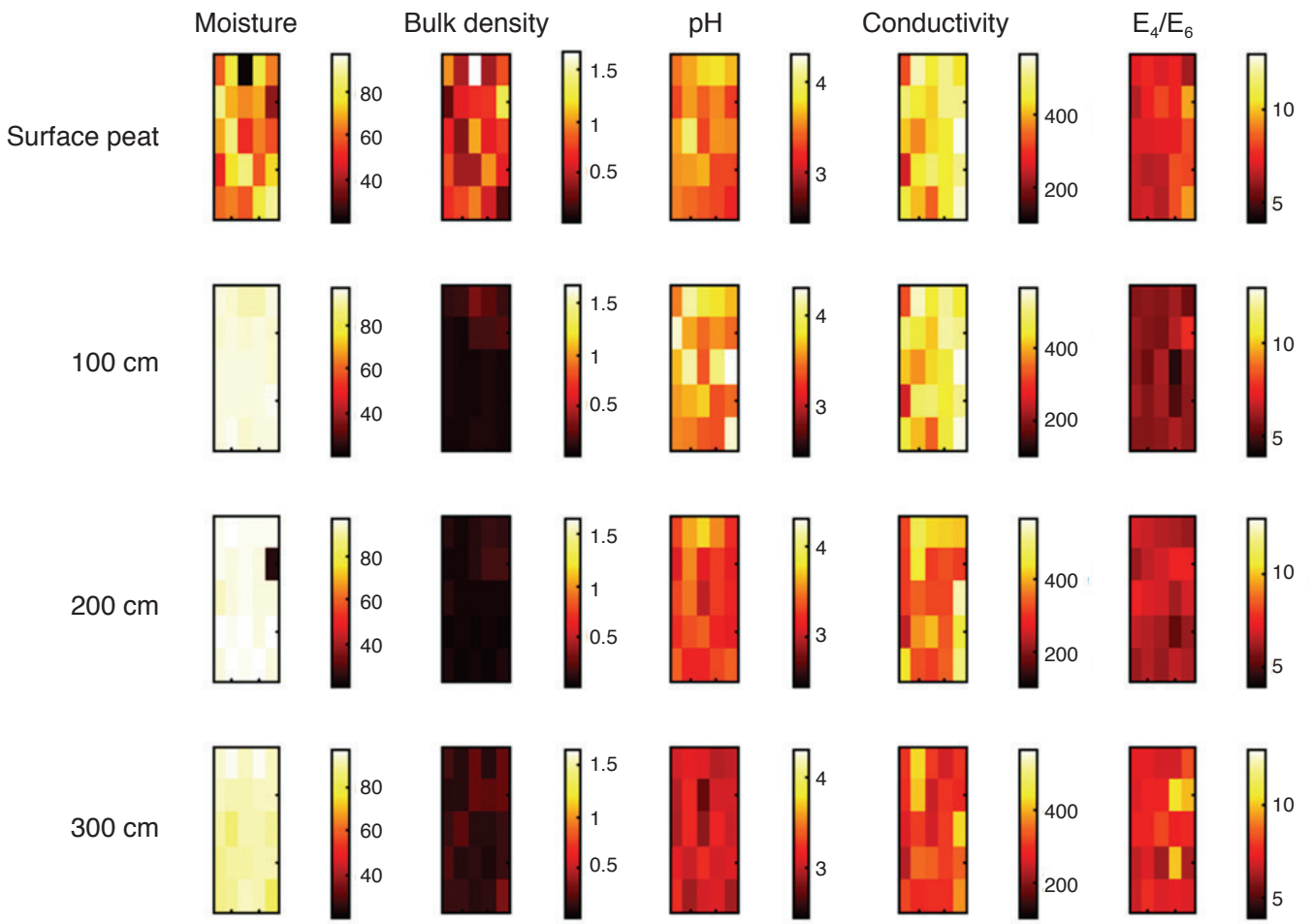

(b) Forest

Figure 4. The profile characteristics maps of peat soil from (a) oil palm plantation and (b) forest. 
TABLE 1. AVERAGE PEAT SOIL CHARACTERISTICS FROM (A) OIL PALM PLANTATION AND (B) FOREST ACCORDING TO PROFILE

\begin{tabular}{|c|c|c|c|c|c|}
\hline \multicolumn{6}{|c|}{ (A) Oil palm plantation } \\
\hline Profile & Moisture (\%) & Bulk density $\left(\mathrm{g} \mathrm{cm}^{-3}\right)$ & $\mathrm{pH}$ & Conductivity $\left(\mu \mathrm{S} \mathrm{cm}^{-1}\right)$ & $\mathrm{E}_{4} / \mathrm{E}_{6}$ \\
\hline Surface & $66.67 \pm 12.78^{\mathrm{a}}$ & $0.64 \pm 0.24^{b}$ & $3.48 \pm 0.23^{c}$ & $317.61 \pm 118.85 a^{b}$ & $7.67 \pm 1.88^{\mathrm{b}}$ \\
\hline $100 \mathrm{~cm}$ & $90.45 \pm 1.69^{b}$ & $0.16 \pm 0.03^{\mathrm{a}}$ & $3.63 \pm 0.29^{c}$ & $322.09 \pm 119.30^{\mathrm{b}}$ & $6.27 \pm 0.93^{\mathrm{a}}$ \\
\hline $200 \mathrm{~cm}$ & $90.70 \pm 4.32^{\mathrm{b}}$ & $0.15 \pm 0.04^{\mathrm{a}}$ & $3.28 \pm 0.20^{\mathrm{b}}$ & $279.65 \pm 102.10 \mathrm{a}^{\mathrm{b}}$ & $7.62 \pm 1.99^{b}$ \\
\hline $300 \mathrm{~cm}$ & $89.42 \pm 2.78^{\mathrm{b}}$ & $0.17 \pm 0.05^{\mathrm{a}}$ & $2.96 \pm 0.22^{\mathrm{a}}$ & $240.74 \pm 82.18^{\mathrm{b}}$ & $8.33 \pm 1.91^{\mathrm{b}}$ \\
\hline \multicolumn{6}{|c|}{ Note: Same letters in a column indicate no significant difference ( $\mathrm{p}>0.05)$. } \\
\hline \multicolumn{6}{|l|}{ (B) Forest } \\
\hline Profile & Moisture (\%) & Bulk density $\left(\mathrm{g} \mathrm{cm}^{-3}\right)$ & $\mathrm{pH}$ & Conductivity $\left(\mu S \mathrm{~cm}^{-1}\right)$ & $\mathrm{E}_{4} / \mathrm{E}_{6}$ \\
\hline Surface & $66.09 \pm 15.58^{a}$ & $0.72 \pm 0.32^{\mathrm{b}}$ & $3.51 \pm 0.19^{c}$ & $451.87 \pm 73.50^{c}$ & $7.44 \pm 0.87^{c}$ \\
\hline $100 \mathrm{~cm}$ & $93.60 \pm 1.18^{b}$ & $0.13 \pm 0.07^{a}$ & $3.70 \pm 0.30^{\mathrm{d}}$ & $456.31 \pm 75.03^{c}$ & $5.94 \pm 0.56^{\mathrm{a}}$ \\
\hline $200 \mathrm{~cm}$ & $92.11 \pm 13.84^{\mathrm{b}}$ & $0.10 \pm 0.04^{\mathrm{a}}$ & $3.31 \pm 0.18^{b}$ & $375.97 \pm 75.77^{\mathrm{b}}$ & $6.59 \pm 0.52^{\mathrm{b}}$ \\
\hline $300 \mathrm{~cm}$ & $90.08 \pm 2.97^{\mathrm{b}}$ & $0.19 \pm 0.06^{\mathrm{a}}$ & $3.05 \pm 0.12^{\mathrm{a}}$ & $316.37 \pm 53.65^{\mathrm{a}}$ & $7.577 \pm 1.06^{\mathrm{c}}$ \\
\hline
\end{tabular}

Note: Same letters in a column indicate no significant difference $(p>0.05)$.

peat to $0.5 \mathrm{~g} \mathrm{~cm}^{-3}$ for well decomposed materials (Andriesse, 1988). The low bulk density of deeper peat agrees with the findings of Veloo et al. (2014) suggesting presence of undecomposed materials within the soil profiles. At the surface, the bulk density was noticeably higher than the underlying soil, which is not unexpected for reclaimed peat including secondary forest, due to drainage.

The $\mathrm{E}_{4} / \mathrm{E}_{6}$ is an index of humification; a lower $\mathrm{E}_{4} / \mathrm{E}_{6}$ suggests greater condensation structure, indicative of higher humification degree and vice versa (Sim etal., 2017). The $\mathrm{E}_{4} / \mathrm{E}_{6}$ values for plantation and forest peat (from varying depths) range between $6.37-8.33$ and $5.94-7.44$, respectively, with the former exhibiting slightly higher value suggesting predominant presence of aliphatic compounds. This observation is in good agreement with the findings of Ywih et al. (2009). Statistically, there was no significant different for samples from varying depths and no observable pattern was deduced suggesting that $E_{4} / E_{6}$ is lacking in sensitivity to distinguish the humification degree. The humification degree was further estimated based on $\mathrm{C} / \mathrm{N}$ ratio of composite subplot samples at different depths; soil with higher humification is expected with a lower $\mathrm{C} / \mathrm{N}$ as a result of greater mobile nitrogen reserve (Sari and Forro, 2008). Figure 5 illustrates the $\mathrm{C} / \mathrm{N}$ profile for peat soil from plantation (34 - 95) and forest sites $(21-60)$. The ratio determined for the surface peat (plantation: 34 and forest: 21) is within the range of 16-41 reported by Yonebayashi et al. (1994). The forest peat consistently demonstrated lower $\mathrm{C} / \mathrm{N}$ ratio $(p<0.05)$ than the plantation peat inferring higher nitrogen reserve for the former. This higher stores of nitrogen in peat soil of the secondary forest over oil palm plantation is likewise reported by Muniandy et al. (2009). This variation is associated with the origin of parent materials, land clearance, water table management, fertiliser application and liming which lead to increase in soil $\mathrm{pH}$ enhancing microbial activity and mineralisation of nitrogen (Muniandy et al., 2009). Wang et al. (2018) concludes that the soil $\mathrm{C} / \mathrm{N}$ is closely related to the land use types with cultivated land demonstrating lower ratio than woodland and orchard. As the depth increased, the peat soil from both cultivated and forest system exhibited increasing $\mathrm{C} / \mathrm{N}$ ratio, indicative of reduction in humification degree. This observation agrees with the findings of Tonk et al. (2017) signifying the undecomposed nature of the underlying tropical peat. This is in opposite to the characteristics of temperate peat where a decline in $\mathrm{C} / \mathrm{N}$ ratio was observed with increasing depths (Vejre et al., 2003; Callesen et al., 2007; Gundersen et al., 2009; Marty et al., 2017). Comparatively, C/N ratio is a more sensitive index of humification over $\mathrm{E}_{4} / \mathrm{E}_{6}$.

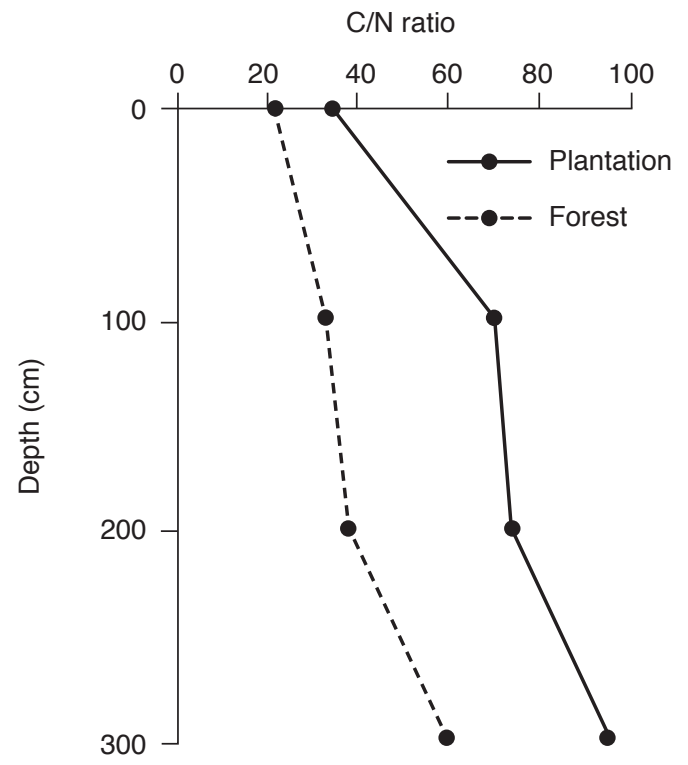

Figure 5. The carbon-to-nitrogen $(\mathrm{C} / \mathrm{N})$ profile of plantation and forest peat. 


\section{CONCLUSION}

The cultivated peat exhibited higher exchangeable $\mathrm{Ca}, \mathrm{K}$ and $\mathrm{CO}_{2}$ flux than the forest peat, attributable to the fertilisation and drainage activities. As the depth increased, the soil $\mathrm{pH}$, conductivity and bulk density were found to reduce in both plantation and forest. The declining bulk density suggested less decomposed nature of the lower layer peat, however, no substantial corroboration was drawn from the humification index of $\mathrm{E}_{4} / \mathrm{E}_{6}$. The $\mathrm{C} / \mathrm{N}$ ratio offered a conclusive indication that the underlying tropical peat is less decomposed with plantation peat showing lower nitrogen reserve. The cultivated and forest peat differed mainly in nutrient availability and $\mathrm{CO}_{2}$ emission with the former demonstrating a lower $\mathrm{C} / \mathrm{N}$ ratio indicative of more pronounced nitrogen mineralisation.

\section{ACKNOWLEDGEMENT}

The work is the collaboration between the Faculty of Resource Science and Technology, Universiti Malaysia Sarawak (UNIMAS) and MPOB.

\section{REFERENCES}

Ahmed, O H; Azrumi, N A; Jalloh, M B and Jol, H (2015). Using clinoptilolite zeolite for enhancing potassium retention in tropical peat soil. Advances in Tropical Soil Science (Jol, H and Jusop, S eds.). Vol. 3. Universiti Putra Malaysia Press, Selangor, Malaysia. p. 112-127.

Ahmed, O H; Husni, M H A; Hanafi, M M; Anuar, A R and Syed Omar, S R (2005). Applied K fertilizer use efficiency in pineapples grown on a tropical peat soil under residues removal. Sci. World J., 5: 42-49.

Andriesse, J P (1988). Nature and management of tropical peat soils. FAO Soils Bull., 59: 45- 46.

ASTM (1987). Standard Test Methods for Moisture, Ash, and Organic Matter of Peat and Other Organic Soils (D 2974-87). American Society for Testing and Materials, Philadelphia, USA. p. 31-35.

Blake, G R (1964). Bulk density. Methods of Soil Analysis. Madison, ASA, USA. p. 383-390.

Callesen, I; Raulund-Rasmussen, K; Westman, C J and Tau-Strand, L (2007). Nitrogen pools and C:N ratios in well-drained nordic forest soils related to climate and soil texture. Boreal Environ. Res., 12: 681692.

Clapp, C E and Hayes, M H B (1999). Sizes and shapes of humic substances. Soil Sci., 164: 777-788.
Gronlund, A; Hauge, A and Hovde, A (2008). Carbon loss estimates from cultivated peat soils in Norway: A comparison of three methods. Nutr. Cycl. Agroecosys., 81: 157-167.

Gundersen, P; Sevel, L; Christiansen, J S; Vesterdal, L; Hansen, K and Bastrup-Birk, A (2009). Do indicators of nitrogen retention and leaching differ between coniferous and broadleaved forests in Denmark? Forest Ecol. Manage., 258: 1137- 1146.

Hergoualc'h, K and Verchot, L V (2013). Greenhouse gas emission factors for land uses and land use change in Southeast Asian peatlands. Mitig. Adapt. Strat. GL., 19: 789-807.

Ishikura, K; Darung, U; Inoue, T and Hatano, R (2018). Variation in soil properties regulate greenhouse gas fluxes and global warming potential in three land use types on tropical peat. Atmosphere, 9: 1-14.

Khan, N A; Fujitake, N; Noda, Y; Suzuki, T and Otsuka, H (2006). Comparison of humic acid fractions derived from thermally created plant residues and natural soils: Spectroscopic and elemental analyses. J. Soil Sci. Plant Nutr., 52: 349360.

Li, Q; Guo, X; Chen, L; Li, Y; Yuan, D; Dai, B and Wang, $S$ (2016). Investigating the spectral characteristics and humification degree of dissolved organic matter in saline-alkali soil using spectroscopic techniques. Front. Earth Sci., 11: 76-84.

Marthews, T R; Riutta, T; Oliveras Menor, I; Urrutia, R; Moore, S; Metcalfe, D; Malhi, Y; Phillips, O; Huaraca Huasco, W; Ruiz Jaén, M; Girardin, C; Butt, N; Cain, R and colleagues from the RAINFOR and GEM networks (2014). Measuring Tropical Forest Carbon Allocation and Cycling: A RAINFORGEM Field Manual for Intensive Census Plots (v3.0). Global Ecosystems Monitoring Network, http:/ / gem.tropicalforests.ox.ac.uk/. DOI: 10.5287/ bodleian:xp68kh42k.

Marty, C; Houle, D; Cagnon, C and Courchesne, F (2017). The relationships of soil total nitrogen concentrations, pools and $\mathrm{C}: \mathrm{N}$ ratios with climate, vegetation types and nitrate deposition in temperate and boreal forests of eastern Canada. Catena, 152: 163-172.

Maryganova, V; Szajdak, L W and Tychinskaya, L (2010). Hydrophobic and hydrophilic properties of humic acids from soils under shelterbelts of different ages. Chem Ecol., 26: 25-33.

McLean, E O (1982). Method of Soils Analysis: Soil pH and Lime Requirement (Page, A L; Baker, E and Ellis, R 
J R eds.). Soil Science Society of America. Madison, Wiley-Interscience. p. 199-225.

Melling, L (2000). Dalat and Mukah Sago Plantation Study (Final report). Department of Agriculture, Sarawak. DOI: 10.13140/RG.2.2.12238.72001.

Melling, L; Goh, K and Uyo, L (2007). Biophysical characteristics of tropical peatland. Proc. of the Malaysian Soil Science Conference. Mukah, Sarawak. p. 1-11.

Minkkinen, K and Laine, J (2006). Vegetation heterogeneity and ditches create spatial variability in methane fluxes from peatlands drained for forestry. Plant Soil, 285: 289-304.

Muniandy, M; Ahmed, O H; Ab Majid, N M and Yusop, M K (2009). Effects of converting secondary forest to oil palm plantation on peat soil carbon and nitrogen and other soil chemical properties. Am J. Environ. Sci., 5: 406-412.

Ott, C A and Chimner, R A (2016). Long-term peat accumulation in temperate forested peatlands (Thuja occidentalis swamps) in the Great Lakes region of North America. Mires and Peat, 18: 1-9.

Paramanathan, S and Omar, W (2015). Soils of the Lower and Middle Baram River Basin Miri Division Sarawak, Malaysia. MPOB, Bangi. 151 pp.

Piccolo, A (2002). The supramolecular structure of humic substances: A novel understanding of humus chemistry and implications in soil science. Adv. Agron., 75: 57-134.

Premke, K; Atterneyer, K; Augustin, J; Cabezas, A; Casper, P; Deumlich, D; Gelbrechy, J; Gerke, H H; Gessler, A; Grossart, H P; Hilt, S; Hupfer, M; Kalettka, T; Lischeid, G; Sommer, $\mathrm{M}$ and Sak, D (2016). The importance of landscape diversity for carbon fluxes at the landscape level: Small-scale heterogeneity matters. WIREs Water, 3: 601-617.

Sari, S J and Forro, E (2008). Relationships between humification and productivity in peat-based and peat-free growing media. Hort. Sci. (Prague), 35: 45-49.

Sim, S F; Wasli, M E; Yong, C M R; Howell, P S; Jumin, C; Safie, N A and Samling, B (2017). Assessment of the humification degree of peat soil under sago (Metroxylon sagu) cultivation based on Fourier transform infrared (FTIR) and ultravioletvisible (UV-Vis) spectroscopic characteristics. Mires and Peat, 19: 1-10.
Suharjo, B H and Nurhayati, A D (2005). Changes in chemical and physical properties of hemic peat under fire-based shifting cultivation. Tropics, 14: 263-269.

Sulistiyanto, Y; Vasander, H; Jauhiainen, J; Rieley, J $\mathrm{O}$ and Limin, S H (2007). Mineral nutrient content of water at different depths in peatland in Central Kalimantan, Indonesia. Proc. of the International Symposium and Workshop on Tropical Peatland. Yogyakarta, Indonesia. p. 77-82.

Tonks, A J; Aplin, P; Beriro, D J; Copper, H; Evers, S; Vane, C H and Sjögersten, S (2017). Impacts of conversion of tropical peat swamp forest to oil palm plantation on peat organic chemistry, physical properties and carbon stocks. Geoderma, 289: 36-45.

US EPA (1986). Cation exchange capacity of soils (ammonium acetate). Method 9080. 9 pp.

Vejre, H; Callesen, I; Vesterdal, L and RaulundRasmussen, K (2003). Carbon and nitrogen in Danish forest soils-contents and distribution determined by soil order. Soil Sci. Am. J., 67: 335-343.

Veloo, R; Paramananthan, S and Van Ranst, E (2014). Classification of tropical lowland peats revisited: The case of Sarawak. Catena, 118: 179-185.

Veloo, R; Van Ranst, E and Selliah, P (2015). Peat characteristic and its impact on oil palm yield. NJAS-Wagen. J. Life Sci., 72-73: 33-40.

Venegas-González, J; Montañez-soto, J L and Cejatorres, L F (2013). Nutrient uptake by blackberry plants grown in greenhouse. Adv. Biores., 4: 144-150.

Wang, S; Adhikari, K; Wang, Q B; Jin, XX and Li, H D (2018). Role of environmental variables in the spatial distribution of carbon $(\mathrm{C})$, nitrogen $(\mathrm{N})$ and $\mathrm{C}: \mathrm{N}$ ratio from the northeastern coastal agroecosystems in China. Ecol. Indic., 84: 263-272.

Yonebayashi, K; Pechayapisit, J; Vijarnsorn, P; Zahari, A B and Kyuma, K (1994). Chemical alterations of tropical peat soils determined by Waksman's proximate analysis and properties of humic acids. Soil Sci. Plant Nutr., 40: 435-444.

Ywih, C H; Ahmed, O H; Majid, N M A and Jalloh, M B (2009). Effects of converting secondary forest on tropical peat soil to oil palm plantation on carbon storage. Am. J. Agri. Bio. Sci., 4: 123-130. 